\title{
Principal Component Analysis of Urban Expansion Drivers in Greater Lagos, Nigeria
}

\author{
Abiodun O.E. ${ }^{1 *}$, Olaleye J.B. ${ }^{1}$, Olusina J.O. ${ }^{1}$ and Omogunloye O.G. ${ }^{1}$ \\ ${ }^{1}$ Department of Surveying and Geoinformatics, University of Lagos, Lagos, Nigeria \\ Corresponding Author: *abiodunoludayo@yahoo.com
}

\begin{abstract}
Urban expansion has been identified as a major cause of global climatic and environmental changes. Accurate and up-to-date information about urban expansion in terms of the drivers responsible for this expansion are important for long term planning and sustainable urban development. Lagos is one of the cities that have undergone rapid urban enlargement in the last few decades and, many factors have been adduced to contribute to its sprawling. Therefore, this study aims at using the Principal Component Analysis (PCA) for identifying the principal drivers of urban expansion in greater Lagos. In this study, a set of fourteen (14) drivers of expansion are considered in a multinucleic structure. A sequence of Landsat images of the study area for 1984, 2001, 2006 and 2013 was acquired and processed to six land use classes: dense, moderate urban, water, vegetation, wetland and mangrove. The study area was partitioned into 25 regular cells of $20 \mathrm{~km}$ by $25 \mathrm{~km} \mathrm{each}$ from where proximate driver values were obtained. The effectiveness of each driver was tested using PCA. The results show that Land Availability accounted for $37.836 \%$ of total variance. This result of this study may form the basis for a renewed attention on land policy in the study area as a way to enhance sustainable development.
\end{abstract}

Keywords: PCA, Expansion, Drivers, Lagos, Criterion, Development

\subsection{Introduction}

Urbanization is increasing in both the developed and developing countries. However, rapid expansion of large cities, and the associated problems of unemployment, poverty, inadequate health, poor sanitation, urban slums and environmental degradation pose a formidable challenge in many developing countries of Africa and particularly Nigeria (Aina, 1992). Lagos, the fastest growing city in West Africa (World Bank, 2004), has witnessed rapid urban sprawl in recent times, annexing nearby villages and spreading fast into the neighbouring states. Urbanization in Lagos is virtually undocumented, "unbenchmarked" and uncontrolled; therefore adequate planning could not be made to prevent adverse consequences which this development could bring. As Lagos, the heart of Nigeria's national economy continues to expand; government is faced with challenges of making it sustainable to attract foreign investors so as to boost the national economy. This has led to the establishment of Lagos Megacity Development Agency (LMDA) by the Federal Government of Nigeria in collaboration with Lagos and Ogun state governments (Mabogunje, 2007). To stem the trend of adverse consequences of urban development and make way for a sustainable development, there is the need for a holistic knowledge of the region's land decision activities and long term environmental impacts (Nwokoro and Dekolo, 2012). This will include knowledge about the physical expansion in Lagos and the driving factors among other issues. The knowledge of principal driving factors of urban expansion will assist in the formulation of appropriate policy around the identified principal drivers for a sustainable development.

Attempts have been made in the past few years to study urban expansion in Lagos. Examples are Nwokoro and Dekolo (2012), Ademola and Tarkashi (2007a), Eyoh et al., (2012), Okwuashi et al., (2009), Onojeghuo and Onojeghuo (2013) and Barredo and Demicheli (2003). However, all previous studies concentrated on Lagos metropolis. Additionally, only Ademola and Tarkashi (2007a) and Eyoh et al., (2012) studied the drivers of urban expansion within Lagos metropolis. However, new drivers of 
urban expansion would be required for consideration since the current study expands beyond Lagos metropolis. This could necessitate the collapse of some previously identified drivers and introduction of new ones in order to accommodate a moderate number of drivers.

Drivers of urban expansion can be divided into two broad classes: the proximate and the underlying causes (Lambin et al., 2003). Proximate causes are the direct and local causes while underlying factors are regional or even global. There is however, a great level of interplay and interactions between these two classes. Meanwhile, these two classes can further be subdivided into six different types of drivers: the effects of the natural variability; population; spatial policy; proximate/economic causes; cultural factor; and economic factor" (Angel et al., 2005; Lambin et al., 2003 and Turner et al., 1995). Drivers used for urban expansion studies are dependent on the purpose of study and the study area. Table 1 presents the different types of drivers used in some previous studies of urban expansion.

Table 1: Drivers of Urban Expansion (modified after Duwal, 2013)

\begin{tabular}{|c|c|c|c|c|c|}
\hline Factors & Fang et al. (2005) & Hu \& Lo (2007) & Priyanto (2010) & $\begin{array}{l}\text { Thapa \& } \\
\text { Murayama (2010) }\end{array}$ & $\begin{array}{l}\text { Ademola \& } \\
\text { Tarkashi (2007a) }\end{array}$ \\
\hline $\begin{array}{l}\text { Natural } \\
\text { Variability }\end{array}$ & $\begin{array}{l}\text { Degree of steepness, } \\
\text { forest, rivers and } \\
\text { lakes }\end{array}$ & Slope percentage & Elevation & Slope, soil, river & $\begin{array}{l}\text { Topographic } \\
\text { Variable }\end{array}$ \\
\hline Population & Population Density & $\begin{array}{l}\text { Population } \\
\text { Density }\end{array}$ & $\begin{array}{l}\text { Annual } \\
\text { Population } \\
\text { growth }\end{array}$ & $\begin{array}{l}\text { High population } \\
\text { influx }\end{array}$ & $\begin{array}{l}\text { Population } \\
\text { variables }\end{array}$ \\
\hline $\begin{array}{l}\text { spatial policy } \\
\text { /Institutional } \\
\text { factor }\end{array}$ & $\begin{array}{l}\text { City development } \\
\text { policy, farmland } \\
\text { preservation policy }\end{array}$ & & & $\begin{array}{l}\text { Zoning, land reform, } \\
\text { investment plans, } \\
\text { land development } \\
\text { plans }\end{array}$ & $\begin{array}{l}\text { Neighbourhood } \\
\text { indices }\end{array}$ \\
\hline $\begin{array}{l}\text { Proximate } \\
\text { /Economic causes }\end{array}$ & $\begin{array}{l}\text { Proximity to major } \\
\text { road intersection, } \\
\text { state highway, } \\
\text { sewage, water, } \\
\text { electricity }\end{array}$ & $\begin{array}{l}\text { Distance to } \\
\text { CBDs, active } \\
\text { economic centres }\end{array}$ & $\begin{array}{l}\text { Proximity to } \\
\text { primary road, } \\
\text { public facilities, } \\
\text { educational } \\
\text { facilities, Health. }\end{array}$ & $\begin{array}{l}\text { Accessibility to } \\
\text { services like } \\
\text { electricity, waste } \\
\text { disposal, open } \\
\text { spaces, recreation }\end{array}$ & $\begin{array}{l}\text { Cost Distance } \\
\text { surfaces }\end{array}$ \\
\hline Cultural factor & $\begin{array}{l}\text { No of immediate } \\
\text { houses }\end{array}$ & $\begin{array}{l}\text { Distance to urban } \\
\text { cluster, number of } \\
\text { cells within } 7 \times 7 \\
\text { cell window }\end{array}$ & $\begin{array}{l}\text { Existing urban } \\
\text { areas, existing } \\
\text { agricultural areas } \\
\text { and existing } \\
\text { ponds }\end{array}$ & & Nearness to water \\
\hline Economic factor & & $\begin{array}{l}\text { Per-capital } \\
\text { income, } \\
\text { employment rate, } \\
\text { poverty rate }\end{array}$ & & $\begin{array}{l}\text { Jobs and business } \\
\text { opportunities, } \\
\text { industries }\end{array}$ & Income potential \\
\hline
\end{tabular}

Principal Components Analysis (PCA) is a statistical tool used for reducing the dimensionality of a data set (Hamidi and Ewing, 2014). It is one of the most widely used methods for spatial data handling because of its simplicity and relative straightforward interpretation. The method is highly suitable when representing complex relationships among a large number of variables. It can be used to transform a set of correlated variables into orthogonal variables. According to Li and Yeh (2002), the major goal of PCA is to reveal hidden structure in a data set. Therefore, PCA is useful for the following: (i) Identify how different variables work together to create the dynamics of the system; (ii) Reduce the dimensionality of the data; (iii) Decrease redundancy in the data; (iv) Filter some of the noise in the data; (v) Compress the data and (vi) Prepare the data for further analysis using other techniques. These capabilities will provide adequate information about principal drivers to contribute to the sustainable development of Lagos Megacity region. Therefore, the aim of this study is to analyze the many drivers of urban expansion from a four-epoch data using the PCA. The epochs are 1984, 2001, 2006 and 2013 which are epochs where cloud-free image data of the study area are available. 
The study area under consideration covers the entire Lagos State and four Local Governments (Ifo, Obafemi-Owode, Ado/Odo Ota and Shagamu) in Ogun State, in the Southwestern part of Nigeria. The study area is as shown in Figure 1.

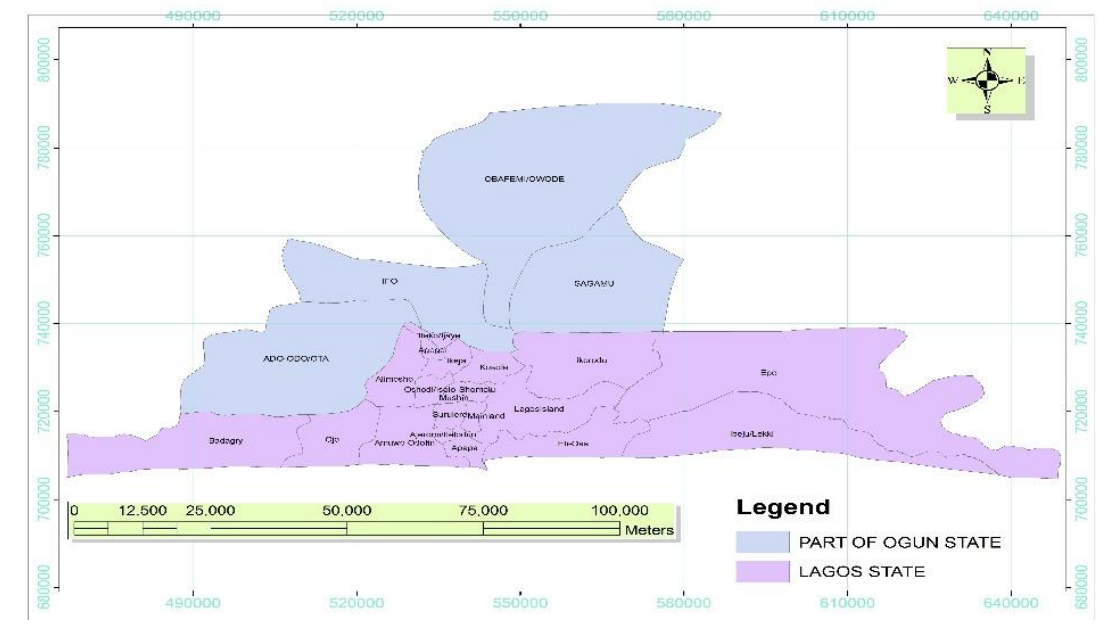

Figure 1: Map of the study area (Source: Author's compilation)

\subsection{Materials and Methods}

The monitoring of changes in urban expansion would be highly relevant and useful when it is accompanied by the adequate understanding of the forces driving change processes (Chen et al, 2014; Geist and Lambin, 2001). This task could be expressed in a linear regression model, which links the response variables (e.g., urban expansion) during a certain interval of time with the changes in causal variables (e.g., human activities) in the corresponding interval of time and across a large number of localities (Shushu and Yong, 2014). This study postulates a linear relationship between the response and causal variables which may be mathematically expressed as shown in Equation 1 (Lambin et al, 2003; Serneel and Lambin, 2001).

$$
A=\beta_{0}+\beta_{1} x_{1}+\beta_{2} x_{2} \ldots+\beta_{n} x_{n}+e
$$

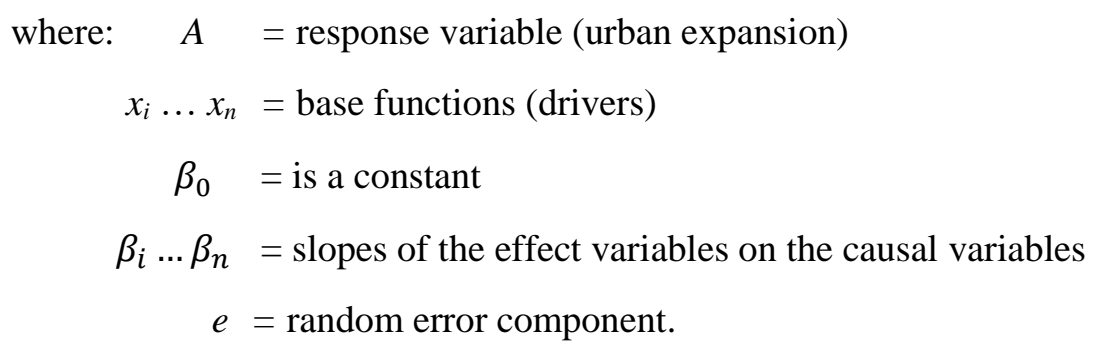

Multi-criteria approach to urban development studies (as used in this work) are usually achieved by using either distances or areas of urban expansion as the response variable (Duwal, 2013). In this work, area of urban expansion was used as the response variable and it was obtained by subdividing the study area into 25 regular cells of $25 \mathrm{~km} \mathrm{X} 20 \mathrm{~km}$. This subdivision (Figure 2) was done such that it largely agrees with Lagos administrative divisions; it considers the shape of the study area and allows opportunity to adequately capture data in each cell. 


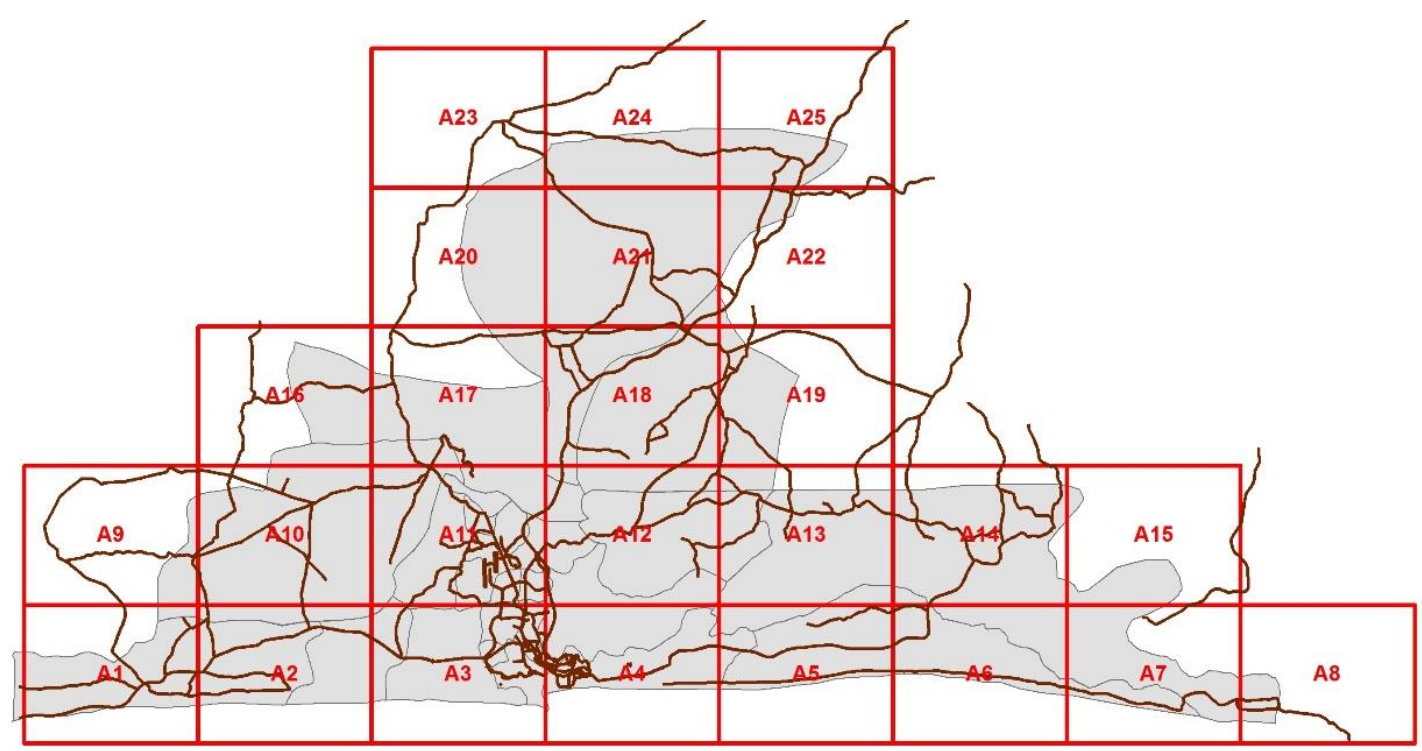

Figure 2: Partitioning of the Study Area into Regular Cells

Decision on the drivers to be included in a model depend on the purpose, extent, location and time of the study (Lambin, 1994). For the purpose of this study, drivers of urban expansion were firstly identified from existing literature. These identified drivers were included in a field survey instrument which was administered to mostly land professionals. Responses from this survey informed the choice of drivers for this study. Therefore, fourteen (14) drivers were identified in this study namely: (i) Distance from Apapa Primary CBD $\left(S_{q}\right)$, (ii) Distance from Lagos Island Primary CBD $\left(S_{g}\right)$, (iii) Distance from Victoria Island (VI) Primary CBD $\left(S_{u}\right)$, (iv) Distance from Ikeja Primary CBD $\left(S_{k}\right)$, (v) Distance from Secondary CBDs $\left(S_{S}\right)$, (vi) Distance from nearest Major Road $\left(S_{R U}\right)$, (vii) Distance from Water Bodies $\left(S_{W U}\right)$, (viii) Distance from Security $\left(S_{C U}\right)$, (ix) Population variable $\left(P_{P}\right)$, (x) Economic Variable (GDP) $(G)$, (xi) Land Availability $\left(L_{A}\right)$, (xii) Area of Water $(W)$, (xiii) Land Value $(D)$, (xiv) Topographic (Elevation) variable $(H)$. Although these drivers have been identified, not all of them will be significant and besides, some of them may be correlated. The Principal Component Analysis (PCA) serves the purpose of assisting to reduce these drivers such that the equations become simple and only relevant drivers are retained.

Modeling urban expansion becomes useful and relevant with the understanding of the forces driving urban expansion. The linear relationship between urban expansion and the drivers can be expressed as stated in Equation 1 above. Introducing all identified drivers into Equation 1, we derive Equation 2.

$$
\begin{aligned}
A_{i(t)}= & \beta_{0}+\beta_{1} S_{q i(t)}+\beta_{2} S_{g i(t)}+\beta_{3} S_{u i(t)}+\beta_{4} S_{k i(t)}+\beta_{5} S_{s i(t)}+\beta_{6} S_{R U i(t)}+\beta_{7} S_{W U i(t)}+ \\
& \beta_{8} S_{C U i(t)}+\beta_{9} P_{p i(t)}+\beta_{10} G_{i(t)}+\beta_{11} L_{A i(t)}+\beta_{12} W_{i(t)}+\beta_{13} D_{i(t)}+\beta_{14} H_{i(t)}
\end{aligned}
$$

All the terms in Equation 2 are defined in Table 2. 
Table 2: Definition of terms in Equation 2

\begin{tabular}{|ll|}
\hline Variable & Definition \\
$A_{i(t)}$ & Area Expansion in cell i at epoch $t$ \\
$S_{q i(t)}$ & Distance from Apapa Primary CBD to location of expansion in cell $i$ at epoch $t$ \\
$S_{g i(t)}$ & Distance from Lagos Island Primary CBD to location of expansion in cell $i$ at epoch $t$ \\
$S_{u i(t)}$ & Distance from VI Primary CBD to location of expansion in cell $i$ at epoch $t$ \\
$S_{k i(t)}$ & Distance from Ikeja Primary CBD to location of expansion in cell $i$ at epoch $t$ \\
$S_{S i(t)}$ & Distance from Secondary CBD to location of expansion in cell $i$ at epoch $t$ \\
$S_{R U i(t)}$ & Distance from Nearest major road to location of expansion in cell $i$ at epoch $t$ \\
$S_{W U i(t)}$ & Distance from Nearest body of water to location of expansion in cell $i$ at epoch $t$ \\
$S_{C U i(t)}$ & Distance from Nearest Security (DPS)* to expansion in cell $i$ at epoch $t$ \\
$P_{p i(t)}$ & Population in cell $i$ at epoch $t$ \\
$G_{i(t)}$ & GDP in cell $i$ at epoch $t$ \\
$L_{A i(t)}$ & Available Land in cell $i$ at epoch $t$ \\
$W_{i(t)}$ & Area of Waterbody in cell $i$ at epoch $t$ \\
$D_{i(t)}$ & Land Value in cell $i$ at epoch $t$ \\
$H_{i(t)}$ & Height of location of expansion in cell $i$ at epoch $t$ above Mean Sea Level (MSL) \\
\hline
\end{tabular}

However, the PCA requires that the principal component $Z i$ is expressed as shown in Equation 3 (Yaya, 2012).

$$
\begin{aligned}
Z_{i}= & \beta_{1} S_{q i}+\beta_{2} S_{g i}+\beta_{3} S_{u i}+\beta_{4} S_{k i}+\beta_{5} S_{s i}+\beta_{6} S_{R U i}+\beta_{7} S_{W U i}+\beta_{8} S_{C U i}+\beta_{9} P_{p i}+\beta_{10} G_{i}+ \\
& \beta_{11} L_{A i}+\beta_{12} W_{i}+\beta_{13} D_{i}+\beta_{14} H_{i}
\end{aligned}
$$

Equation 3 could be simplified and expressed as found in Equation 4.

$Z_{i}=X v_{i}$

Where, $v_{i}=\beta_{1}, \beta_{2}, \ldots \beta_{n}$ is a vector of weights and $X$ is the vector of dependent variables.

The principal component $Z_{i}$ is determined such that the overall variance of the resulting point is as large as possible. The weights must be calculated with the constraint that their sum of squares is one to prevent large variance of $Z_{i}$ which could be as a result of large values of weights. According to Zou et al., (2006), PCA determines $v_{i}$ so that

$$
\operatorname{Var}\left(Z_{i}\right)=\frac{1}{n} \sum_{i=1}^{n} Z_{i}^{2}=\frac{1}{n} v_{i}^{\prime} X^{\prime} X v_{i} \text { is maximal }
$$

The correlation matrix of the variables can be given by Equation 6 .

$$
C=\frac{1}{n} X^{\prime} X
$$

The problem therefore is to search for a unit vector $v_{i}$ so as to maximize the variance of $Z_{i}$ in Equation 5 . The technique used for solving such vector space optimization problems involves the construction of a Lagrangian function (see Ayeni, 2001; Neter et al., 2005 and Lindsay, 2002) which results in Equation 7.

$$
C v_{i}=\lambda_{i} v_{i}
$$

Where $\lambda_{i}$ is the Langrangian constant. 
Multiplying each side of Equation 7 by $v_{i}^{\prime}$ and using the condition $v_{i}^{\prime} v_{i}=1$, we derive Equation 8 .

$v_{i}^{\prime} C v_{i}=\lambda_{i} v_{i}^{\prime} v_{i}=\lambda_{i}$

It is known from matrix algebra that any value of $\lambda_{i}$ and $v_{i}$ for which Equations 7 and 8 has a solution are the maximum eigenvalue and the corresponding eigenvector of the correlation matrix $C$ (Haiping $e t$ al., 2008).

From the eigenvalues, decisions are taken on the components of lesser significance that might be ignored. Although information are lost by ignoring insignificant components, this is negligible if the eigenvalues are small (Lindsay, 2002). There are three methods described in existing literature for determining meaningful components of an effect variable ( $\mathrm{Li}$ and Yeh 2002). These methods are:

(a) The Eigenvalue-one Criterion: In this approach, components with eigenvalue greater than one are considered to be meaningful to the response variable. Some researchers criticize this approach and argued that eigenvalue of one (1) and 0.9 are not significantly different, yet one would be retained and the other would be removed. They further argued that a component with percentage eigenvalue of not less than $1 \%$ could still be considered to be meaningful especially when all the components are less than 30 (Swan and Sandilands, 1995).

(b) The Cumulative Variance: In the cumulative variance approach, components that account for a cumulative percentage variance of at least $80 \%$ are considered meaningful to response variable. Other components with cumulative percentage variance of less than $80 \%$ are ignored.

(c) The Scree Test: With the Scree test, the eigenvalues are plotted with associated components. The component at the sharp break of the graph and the ones before it, are considered meaningful. Sometimes, a scree plot will display several breaks, in such a situation, the last break before the graph levels up is considered meaningful (Dunteman, 1989).

These three approaches were considered in this study and the outcome of each approach are discussed under Result section.

\subsection{Data Acquisition}

Image data were acquired from the Global Land Cover Facility (GLCF) of the University of Maryland, USA. Four epoch images were used in this study due to cloud cover limitation. Other data acquired for this study are as shown in Table 3.

Table 3: Other data acquired for the study

\begin{tabular}{|lll|}
\hline S/N & Data & Source \\
1 & Administrative Map of Lagos State & Office of the Surveyor General, Lagos State Secretariat, Alausa \\
2 & Lagos State Road Network Map & Office of the Surveyor General, Lagos State Secretariat, Alausa \\
3 & Population Data & $\begin{array}{l}\text { National Population Commission's office, Lagos State } \\
\text { Headquarters, Surulere, Lagos }\end{array}$ \\
4 & Topography Data & Shuttle Radar Topographic Mission (SRTM) \\
5 & Land Value & $\begin{array}{l}\text { Field survey and Ukabam (2010), Lagos Journal of } \\
\text { Environmental Science }\end{array}$ \\
6 & $\begin{array}{l}\text { Lagos GDP and Lagos Population } \\
\text { Economic Activities data }\end{array}$ & $\begin{array}{l}\text { Lagos Bureau of Statistics, Ministry of Economic Planning and } \\
\text { Budget, Lagos State. }\end{array}$ \\
\hline
\end{tabular}

Based on a priori knowledge of the study area and reconnaissance survey with additional information from previous researches in the study area, a classification scheme (after Anderson, 1976) was 
developed. The land use classifications scheme used in this study is contained in Table 4. A satisfying and reliable supervised classification approach mostly adopted by many researchers is the Maximum Likelihood classification (Brito et al., 2006) and was used in this study.

Table 4: The Classification Schemes used for the study

\begin{tabular}{|llll|}
\hline S/No & Classes & Description & Broad Classification \\
1 & Dense Urban & $\begin{array}{l}\text { All residential, commercial and industrial areas, villages } \\
\text { settlements and transportation infrastructure }\end{array}$ & Developed \\
2 & $\begin{array}{l}\text { Moderate } \\
\text { Urban }\end{array}$ & $\begin{array}{l}\text { Fallow land, earth and sand infillings, construction and } \\
\text { excavation sites and open space. }\end{array}$ & \\
4 & Mangrove & Mangrove forests & Undeveloped \\
5 & Vegetation & $\begin{array}{l}\text { Trees, shrub land, semi natural vegetation and mixed forests, } \\
\text { climbers, gardens and grasslands. } \\
\text { River, permanent open water, lakes, ponds, canals and }\end{array}$ & \\
6 & Water Body & reserviors. \\
& Wetland & Marshy areas susceptible to flooding & \\
\hline
\end{tabular}

The outcomes of image processing are as presented in Figures $3 \mathrm{a}$ to $3 \mathrm{~d}$ while the accuracy assessment report is presented in Table 5. Accuracy assessment results show that the least overall accuracy is $85.77 \%$ and the least Kappa coefficient is 0.8132 . Overall processing accuracy of $85 \%$ and above is considered suitable for urban expansion studies while a Kappa coefficient of 0.8 and above are interpreted as almost perfect accuracy (Anderson, 1976; Landis and Koch, 1977 and Eastman, 2009).

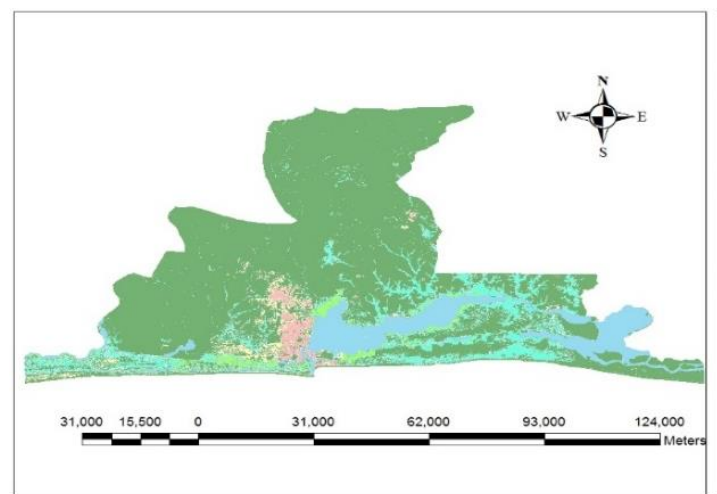

Figure 3a: Outcome of 1984 Image processing

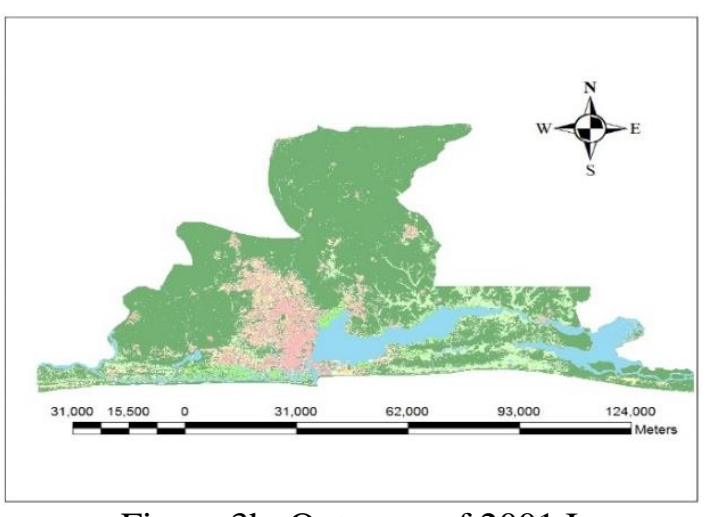

Figure 3b: Outcome of 2001 Image

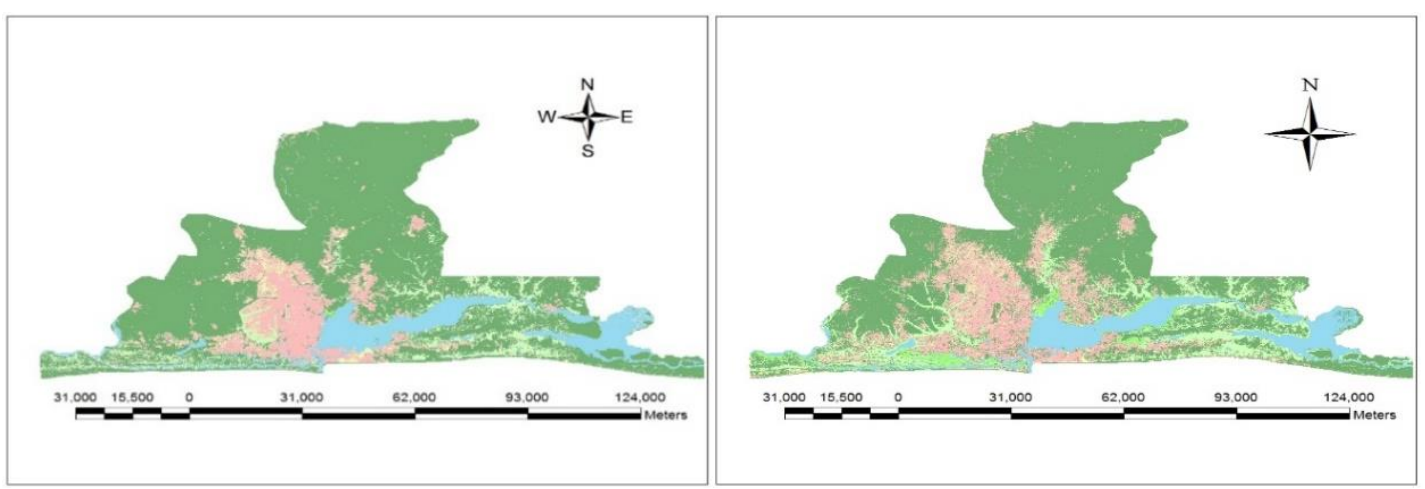

Figure 3c: Outcome of 2006 Image

Figure 3d: Outcome of 2013 Image processing

Legend
Wetlands
Vegetation
Mangroves
Waterbody
Moderate Urban
Dense Urban

Table 5: Accuracy Assessment Results of processed images 


\begin{tabular}{|ccc|}
\hline Image Epoch & Accuracy & Kappa Coefficient \\
1984 & $94.91 \%$ & 0.9265 \\
2001 & $91.77 \%$ & 0.8694 \\
2006 & $94.22 \%$ & 0.8780 \\
2013 & $85.77 \%$ & 0.8132 \\
\hline
\end{tabular}

After image processing, base function values were estimated from the processed images of 1984, 2001, 2006 and 2013; and from additional data acquired for this study as presented in Table 2. For all CBD base functions, coordinates of waypoints along the major roads from the CBDs to points of expansion were acquired. Values of distance from road, distance from water and distance from security were estimated using coordinates of points of expansion and the nearest major road, waterbody and police station respectively. Population data was acquired from National Population Commission and the population values in each cell was estimated by identifying the population of enumeration localities in each cell. For GDP base function, ranking of Economic Activities (EA) used by Braimoh and Onishi (2007) based on the World Development Report (World Bank, 2004) was used to obtain GDP weight in each cell. Land value data published in Ukabam (2010) supported by additional field survey data were used in this study to estimate land value at each epoch while elevation data was obtained from the Shuttle Radar Topographic Mission (SRTM), acquired at regular interval of $500 \mathrm{~m}^{2}$. Figure 4 below shows the distribution of the CBDs, Divisional Police Stations and locations of Economic Activities (EA).

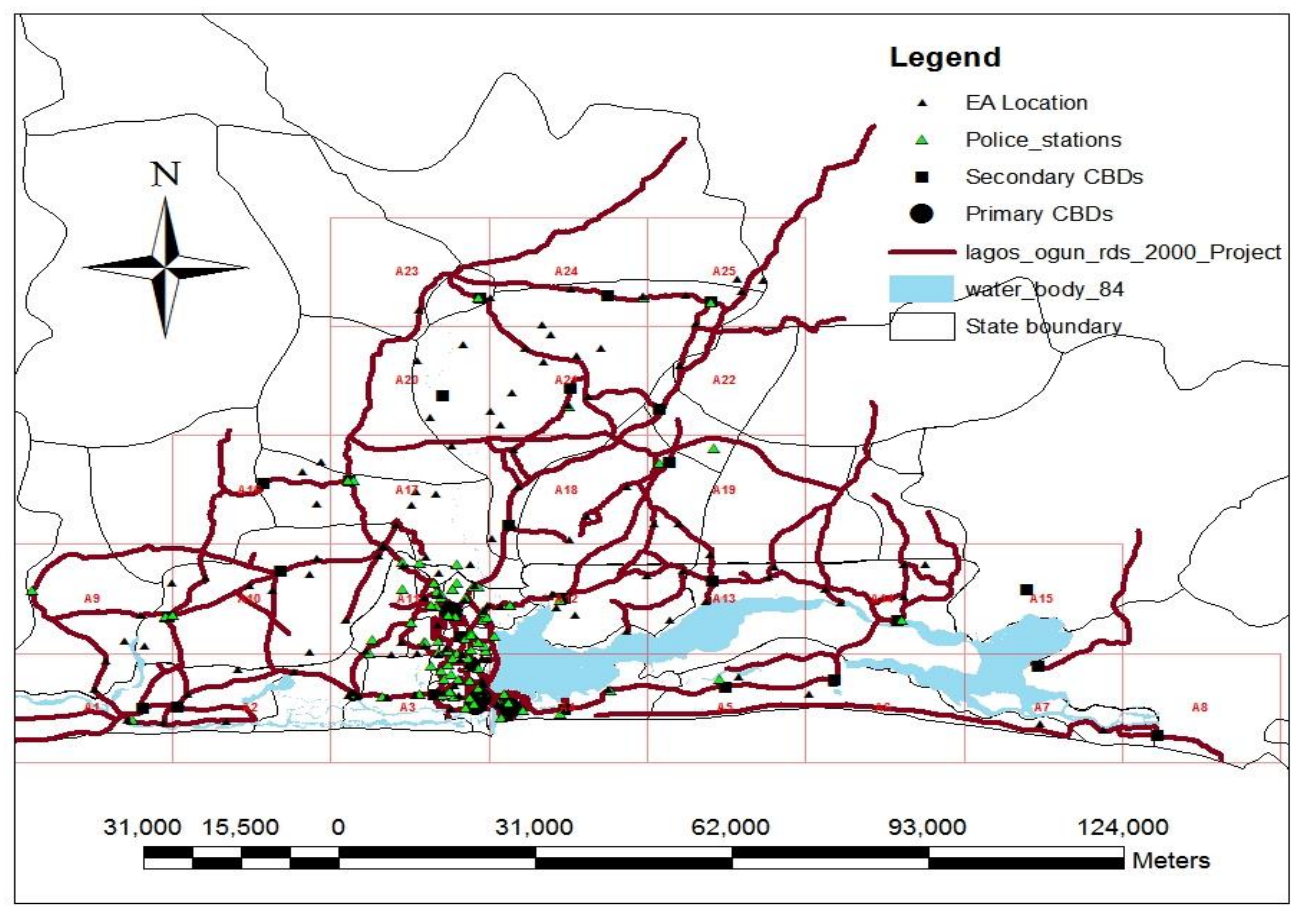

Figure 4: Map showing the CBD, locations of economic activities, major roads and water

\subsection{Results and Discussions}

The results of the PCA in this study are presented in Table 6 and Figures 5 and 6. In PCA, the number of components extracted is equal to the number of components being analyzed (Hamidi and Ewing, 2014). It therefore becomes necessary to decide how many of these components are truly meaningful to the response variable. In general, one would expect that the first few components will account for meaningful amount of variance. 
Using "eigenvalue-one criterion" in the present study, the components with eigenvalue higher than one are four (Table 6): Land Availability $\left(L_{A}\right)$, Land Value $(D)$, Area of Water $(W)$ and GDP $(G)$. However, Population $\left(P_{p}\right)$ with eigenvalue 0.95 would be excluded. Meanwhile, if percentage variance is used and components of eigenvalue $1 \%$ and above are included, then Population $\left(P_{p}\right)$, Distance from Victoria Island $\left(L_{v}\right)$ Distance from Water $\left(S_{W}\right)$, Distance from Secondary CBD $\left(S_{s}\right)$, Distance from Lagos Island $\left(L_{g}\right)$ and Distance from Apapa $\left(L_{a}\right)$ would be included in the model.

Table 6: Eigenvalues from Principal Component Analysis

\begin{tabular}{|ccccc|}
\hline & & & Eigenvalues & \\
\cline { 3 - 4 } Driver & Component Number & Total & \% of Variance & Cumulative \% Variance \\
\cline { 3 - 4 }$D$ & 1 & 5.297 & 37.836 & 37.836 \\
$W$ & 2 & 2.145 & 15.321 & 53.156 \\
$L_{A}$ & 3 & 1.719 & 12.277 & 65.433 \\
$P_{p}$ & 4 & 1.245 & 8.895 & 74.329 \\
$S_{u}$ & 5 & 0.951 & 6.793 & 81.121 \\
$S_{w}$ & 6 & 0.822 & 5.871 & 86.992 \\
$S_{s}$ & 7 & 0.63 & 4.502 & 91.494 \\
$S_{g}$ & 8 & 0.572 & 4.086 & 95.579 \\
$S_{q}$ & 9 & 0.354 & 2.525 & 98.105 \\
$S_{k}$ & 10 & 0.159 & 1.135 & 99.24 \\
$S_{R}$ & 11 & 0.058 & 0.415 & 99.656 \\
$S_{c}$ & 12 & 0.029 & 0.205 & 99.861 \\
$H$ & 13 & 0.019 & 0.139 & 100 \\
\hline
\end{tabular}

From Table 6 , the cumulative percentage variance of $80 \%$ is on component four (GDP). These drivers are the same drivers included by the Eigenvalue one criterion.

The scree plot of the current analysis is as shown in Figure 5. If the first large break in this plot is considered, then only Land Availability and Land Value would be retained in the model. However, the figure display four breaks (as highlighted in Figure 5). The last break before the plot levels is on the tenth component. If the last break before the level is considered, the tenth component would be considered significant to urban expansion. Incidentally, these ten drivers are the same drivers retained by percentage variance of $1 \%$ and above.

Finally, PCA compressed the fourteen drivers into three. The PCA compressed components are a set of new drivers derived from the initial drivers supplied for analysis. The compressed components are as presented in Figure 6. 


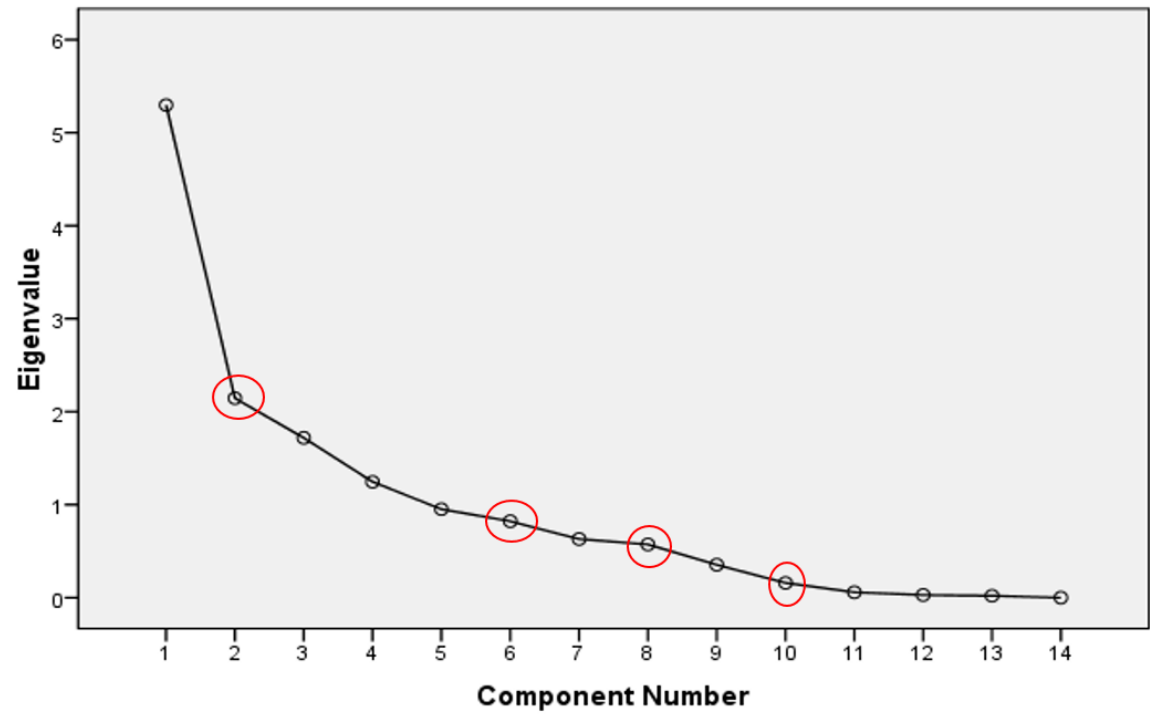

Figure 5: Scree Plot of the Principal Component Analysis

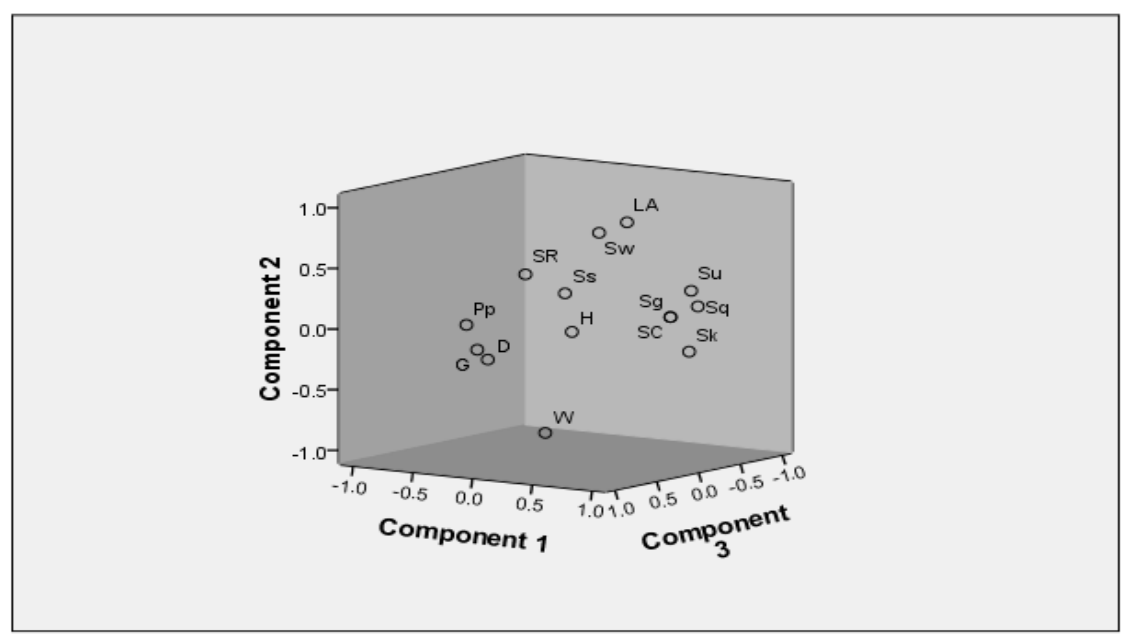

Figure 6: Compressed components in Rotated Space

From Figure 6, Population, Economic data (GDP in this case) and Land value data could be compressed to one. The rest of the variables other than water area could be compressed to one while area of water remain as one component. It would be observed that the drivers retained by the Eigenvalue one criterion are present in each of the compressed component. However, Economic variable and Land Value both significant driver in the Eigenvalue one criterion are compressed to one component.

Three basic criteria for identifying drivers that are truly significant to response variable were examined. The Eigenvalue one criterion retained four drivers. These are: Land Availability, Land value, Area of Water and Economic variable. However, studies in existing literature (e.g. Abiodun et al., 2015) revealed that Land value is driven by Economic variable. This reason could justify the results of the compressed component presented in Figure 6 which revealed that urban expansion drivers in Greater Lagos could be addressed by three compressed components. These are "Factors of Economy", "Factors of Land" and "Factors of Water". The cumulative variance method included five drivers, which are the four drivers included by the Eigenvalue one criterion and Population. In the compressed components, Population is also included in the Economic variable. This is a justification of a common knowledge that man (Population) is the driver of economy. In a sustainable economy, higher population is expected to translate into higher work force and productivity. The scree plot criterion included two drivers at the first break of the graph. These drivers could be referred to as the principal components. Actually, the component with the highest Eigenvalue is considered as the principal component which in this case is Land availability, however, the number of principal components is the opinion of the researcher and the purpose of study. The two drivers under discussion here are somehow interrelated. The value of land would be higher at locations where there is less available land for development and vice-versa. These 
two drivers could therefore be treated together as the principal components of this study. The fourth break of the scree plot included ten drivers. The ten drivers accounted for a cumulative variance of 99.24\%. (Table 6). It is evident from this result that the last four drivers are insignificant and could be excluded from a prediction model.

\subsection{Conclusion}

This paper examines fourteen drivers of urban expansion in Greater Lagos using the Principal Components Analysis (PCA). The following are the conclusions based on the results of the study.

i. Land Availability with the highest eigenvalue has been identified as the principal component. However, Land value, which sometimes could be a function of Land availability has the second highest eigenvalue could be addressed together with Land availability as the principal components for a holistic policy formulation.

ii. Three new drivers derived from the initial fourteen drivers by PCA are Economy, Land and Water. These three drivers could be used to derive a new model for urban expansion prediction or for the purpose of policy formulation.

iii. Four drivers (Distance from Ikeja, Distance from major roads, Distance from security and Elevation) out of the fourteen drivers considered could be completely ignored in urban expansion prediction in Greater Lagos because both eigenvalue and percentage eigenvalue are less than one.

Based on the results and discussions from this study, the following are the recommendations.

i. There is the need for land use reform in the study area in line with the principal drivers identified in this study to ensure sustainable urban expansion;

ii. This study should be extended to cover Lagos, Ogun and Oyo states in order to have better understanding of factors responsible for urban expansion in these three states of Nigeria.

iii. Government and other relevant agencies should address "Factors of Economy", "Factors of Land" and "Factors of Water" as identified in this study in order to ensure sustainable development.

\section{References}

Abiodun O. E., Olaleye J. B., Olusina J. O. and Omogunloye O. G. (2015), "Patterns and Drivers of Urban Expansion in Greater Lagos from 1984 to 2005". Journal of Environmental Sciences and Resources Management, 7 (2), 35-42.

Ademola K. Braimoh, and Takashi Onishi (2007a), "Spatial determinants of urban land use change in Lagos, Nigeria”. Land Use Policy, 24, 502-515.

Aina, Tade Akin (1992), Land Tenure in Lagos, Habitat International, 16 (1), 3-15.

Ajoke Onojeghuo and Alex Onojeghuo (2013), Mapping and Predicting Urban Sprawl Using Remote Sensing and Geographic Information System Techniques: A Case Study of Eti Osa Local Government Area, Lagos, Nigeria. FIG Working Week Environment for Sustainability, Abuja, Nigeria.

Anderson, J.R., Hardy E.E, Roach J.T., and Witmer R.E. (1976), "A Land Use and Land Cover Classification System for Use with Remote Sensor Data". Geological Survey Professional Paper No. 964, U.S. Government Printing Office, Washington, D.C. p. 28.

Angel S., Sheppard S. C., and Civco D. L. (2005), "The Dynamics of Global Urban Expansion". Transport and Urban Development Department, The World Bank, Washington D.C, pp. 241.

Ayeni O. O. (2001), "Statistical Adjustment and Analysis of Data with Applications in Surveying and Photogrammetry”, Department of Surveying and Geoinformatics, University of Lagos.

Barredo Jose' I. and Demicheli Luca (2003), "Urban Sustainability in Developing Countries' Megacities: Modelling and Predicting Future Urban growth in Lagos". Cities, 20 (5), 297-310. 
Brito I, Celeux G, Rerreira AS (2006). Combining Methods in Suoervised Classification: A Comparative Study on Discrete and Continuous Problems. REVSTAT-Statistical Journal, 4(3), 201225 .

Chen M, Zhang H, Liu W, Zhang W (2014) The Global Pattern of Urbanization and Economic Growth: Evidence from the Last Three Decades. PLoS ONE, 9 (8), 1-15.

Dunteman, G.H., (1989), Principal Components Analysis, SAGE Publication Inc., London, U.K., pp. 51

Duwal Sunita (2013), "Modeling Urban Growth in Kathmandu Valley", M.Sc. Thesis, Faculty of Geoinformation Science and Earth Observation, ITC. Enshede.

Eastman J. R. (2009) "IDRISI Taiga Guide to GIS and Image Processing", (Manual Version 16.02) (Software), Clark Labs: Clark University, Massachusetts, USA.

Eyoh A., Olayinka D. N., Nwilo P. C., Okwuashi O., Isong M., and Udoudo D. (2012), "Modelling and Predicting Future Urban Expansion of Lagos, Nigeria from Remote Sensing Data Using Logistic Regression and GIS". International Journal of Applied Science and Technology, 2 (5), 116-124.

Fang S., Gertner G.Z., Sun S. and Anderson A. A. (2005). The Impact of Interactions in Spatial Simulations of the Dynamics of Urban Sprawl. Landscape and Urban Planning, 73 (4), 294-306

Geist, H. and Lambin, E.F., (2001), "What drives tropical deforestation?" LUCC Report Series No.4, LUCC International Project office, University of Louvain.

Haiping L., Plantaniotis K. N. and Venetsanopoulos A. N (2008), "Multilinear Principal Component Analysis of Tensor Objeccts". Neural Networks, 19, (1), 18-39.

Hamidi S. and Ewing R. (2014), A Longitudinal Study of Changes in Urban Sprawl Between 2000 and 2010in the United States. Landscape and Urban Planning, 128, 72-82.

Hu Z. and Lo C.P. (2007), "Modelling urban growth in Atlanta using logistic regression". Computers, Environment and Urban Systems, 31, 667-688.

Hodgson, I. O. A., Obiri S., Cobbina S. J., Quarcoo G. and Duah A. A. (2013), "Principal component analysis of groundwater quality data underlying Geochemical processes of Dahomeyan formation and Togo series in the Ho Municipality (Ghana)". Journal of Applied Science and Technology, Vol. 18 (12) pp. 48-54.

Lambin, E.F., (1994), "Modelling Deforestation Processes A Review". Tropical Ecosystem Environment Observations by Satellites (TREES) series B: Research Report No1, EUR15744EN, p.45101, European Commission, Brussels, Belgium.

Lambin E. F., Geist H. J. and Lepers E. (2003), Dynamics of Land-Use and Land-Cover Change in Tropical Regions. Annual Review of Environment and Resources, 28, 205-241

Landis, J. R. \& Koch, G. G. (1977). The measurement of observer agreement for categorical data. Biometrics, 33,159 - 174.

Li Xia and Yeh Anthony Gar-On, (2002), "Urban Simulation Using Principal Components Analysis and Cellular Automata for Land-Use Planning". Photogrnmrnetric, Engineering \& Remote Sensing 68, (4), 341-351.

Lindsay, I. Smith (2002), "A Tutorial on Principal Component Analysis". Available at www.cs.otago.ac.nz/student/tutorial. 1- 26, Accessed on April 8, 2016.

Mabogunje A. L. (2007), "Developing Megacities in Developing Countries". Colloquium Lecture Series, Department of Geography, University of Lagos.

Neter J., Kunter M. H., Nachtsheim C. J., Wasserman W. (2005), “Applied Linear Statistical Models”, Fifth Edition, McGraw-Hill Inc., New York. 
Nwokoro I. I. C. and Dekolo S. O. (2012), "Land use change and environmental sustainability: the case of Lagos Metropolis", in Pacetti, G. Passerini, C.A. Brebbia, G. Latini, (eds) The Sustainable City VII: Urban Regeneration and Sustainability, witpress, pp 157-167.

Okwuashi O., McConchie J., Morrison P., Nwilo P. and Eyo E. (2009), "Enhancing a GIS Cellular Automata Model of Land Use Change Using Support Vector Machine". 17 $7^{\text {th }}$ International Conference on Geoinformatics Fairfax, Virginia, USA.

Priyanto A. T. (2010), "The Impact of Human Activities on Coastal Zones and Strategies Towards Sustainable Development, a Case Study in Pekalongan, Indonesia". University of Twente, Faculty of Geoinformation and Earth Observation, ITC, Enschede, pp. 55.

Serneel, S. and Lambin E.F., (2001), "Proximate cause of land-use change in Narok District, Kenya: a spatial statistical model". Agriculture, Ecosystem and Environment, 85, 65-81.

Shushu Li and Yong Ma (2014), "Urbanization, Economic Development and Environmental Change". Sustainability, 6, 5143-5161

Swan, A.R.H., and M. Sandilands, (1995), Introduction to Geological Data Analysis. Blackwell Science: Oxford, pp. 446.

Thapa R. B. and Murayama Y. (2010), Drivers of Urban Growth Modelling in Kathmandu Valley, Nepal: Examining the Efficacy of the Analytic Hierarchy Process. Appled Geography, 30 (1), 70-83

Turner, B.L. II, D. Skole, S. Sanderson, G. Fischer, L. Fresco, and R. Leemans (1995), "Land-Use and Land-Cover Change; Science/Research Plan". IGBP Report No.35, HDP Report No.7. IGBP and HDP, Stockholm and Geneva, pp. 188.

Ukabam T. A. (2010), "Factors Affecting the Spatial Distribution of Land Values in Lagos Metropolis". The Lagos Journal of Environmental Studies. 7, (1), 104-114.

World Bank (2004), "World Development Report”, World Bank. New York.

Yaya Keho (2012), "The Basics of Linear Principal Component Analysis, in Principal Component Analysis, Parinya Sanguansat (Ed.), InTech: Shangai, pp. 300. Available from http://www.intechopen.com/books/principal-component-analysis/the-basics-of-principal-componentanalysis.

Zou H., Hastie T. and Tibshirani R. (2006), "Sparse Principal Component Analysis". Journal of Computational and Graphical Statistics, 15, (2), 265-286. 